\title{
Congenital Neutropenia in Children: Evaluation of Infectious Complications, Treatment Results and Long-Term Outcome
}

\section{Işık Odaman Al $\odot$ Yeşim Oymak $\odot$ Tuba Hilkay Karapınar $\odot$ Melek Erdem $\odot$ Salih Gözmen $\odot$ Neryal Tahta $\odot$ Sultan Okur Acar $\odot$ ilknur Çağlar $\odot$ Nuri Bayram $\odot$ ilker Devrim ๑}

\author{
Konjenital Nötropenili Çocuklarda Enfeksiyon \\ Ataklarının, Tedavi ve Uzun Dönem Sonuçlarının \\ Değerlendirilmesi
}

Received: 25.01 .2021

Accepted: 30.04 .2021

Published Online: 03.08.2021

Objective: Infections are an important cause of morbidity and mortality for patients with congenital neutropenia. In the present study, we report on the incidence, type, localization of documented infections, as well as the clinical features and long-term outcome in patients with congenital neutropenia in our clinic.

Method: We performed a retrospective chart review of children with neutropenia seen at our hospital from 2000-2018. The data of 15 patients with congenital neutropenia were included in this study. Clinical and laboratory data were analyzed retrospectively using patients' files and an electronic data system. Results: The median age at diagnosis was 34 months (range, four months- 150 months) and the median follow-up time was 48 months (range, 13-179 months). The leading causes of hospital admission before the establishment of the diagnosis were upper respiratory tract infection in six, pneumonia in four, gingival stomatitis in three and soft tissue infection in two patients. We reached the documented 74 hospitalization episodes and the most common reasons for hospitalization were pneumonia (35\%), fever (21\%), stomatitis $(16 \%)$, cutaneous and deep soft tissue infections (12\%).

Conclusion: The management of infectious complications in children with congenital neutropenia is crucial. Early diagnosis is essential to prevent infections and permanent organ damage. Congenital neutropenia should be suspected in patients with a history of frequent upper respiratory tract infection, and necessary investigations should be performed accordingly. However, it should be kept in mind that the clinical findings of the patients may vary despite having the same mutation.

Keywords: Congenital neutropenia, infection, neutropenia, children

öz

Amaç: Enfeksiyonlar konjenital nötropeni hastalarında önemli bir morbidite ve mortalite nedenidir. Bu çalışmada konjenital nötropeni hastalarının geçirdiği enfeksiyon ataklarının sıkı̆̆ını, tipini ve bölgesini klinik bulgular ve uzun dönem sonuçları ile birlikte değerlendirdik.

Yöntem: Hastanemizde 2000-2018 yılları arasında konjenital nötropeni tanısı ile takip edilen 15 hasta çalışmaya alındı. Hastalara ait klinik ve laboratuvar bilgileri hasta dosyaları ve elektronik kayıt sistemi kullanılarak retrospektif olarak incelendi.

Bulgular: Çalışmaya dahil edilen 15 hastanın ( 6 erkek, 9 kız) medyan tanı yaşı 34 ay (aralık, 4 ay - 150 ay), medyan izlem süresi 48 ay (aralık, 13 ay -179 ay) idi. Hastaların tanı öncesi en sık hastaneye başvuru nedeni 6 hastada üst solunum yolu enfeksiyonu, 4'ünde alt solunum yolu enfeksiyonu, 3'ünde stomatit ve 2'sinde cilt bulguları idi. Yetmiş dört hastane yatış episoduna ulasıldı. En sık hospitalizasyon nedeni alt solunum yolu enfeksiyonu (\%35), ateş (\%21), stomatit (\%16), cilt ve derin doku enfeksiyonu (\%12) idi.

Sonuç: Konjenital nötropenili hastalarda enfeksiyonların yönetimi çok önemlidir. Erken tanı, enfeksiyon ataklarını ve kalıcı organ hasarını önlemek için gereklidir. Sık üst solunum yolu enfeksiyonu geçiren hastalarda konjenital nötropeniden şüphelenilmeli ve gerekli araştırmalar yapılmalıdır. Aynı mutasyonu taşımalarına rağmen klinik bulguların değişken olabileceği akılda tutulmalıdır.

Anahtar kelimeler: Konjenital nötropeni, infeksiyon, nötropeni, çocuk
Cite as: Odaman Al I, Oymak Y, Karapınar TH, Erdem M, Gözmen S, Tahta N, Okur Acar S, Çağlar I, Bayram $\mathrm{N}$, Devrim i. Congenital neutropenia in children: evaluation of infectious complications, treatment results and long-term outcome. İzmir Dr. Behçet $\mathrm{Uz}$ Çocuk Hast. Dergisi. 2021;11(2):181-7.

Işık Odaman Al Dr. Behçet Uz Çocuk Hastalıkları ve Cerrahisi EAH, Çocuk Hematoloji ve Onkoloji Bilim Dalı

İzmir, Türkiye dr.odamanal@gmail.com ORCID: 0000-0003-4292-1409

Y. Oymak 0000-0002-6908-8309

T.H. Karapınar 0000-0002-4714-332X

S. Gözmen 0000-0002-8585-9628

N. Tahta 0000-0001-6939-1570 Dr. Behçet Uz Çocuk Hastalıkları ve Cerrahisi EAH, Çocuk Hematoloji ve Onkoloji Bilim Dalı izmir, Türkiye

M. Erdem 0000-0003-4273-7951 Uludağ Üniversitesi Tıp Fakültesi, Çocuk Hematoloji ve Onkoloji Bilim Dalı, Bursa, Türkiye Başakşehir Çam ve Sakura Şehir Hastanesi, Çocuk Hematoloji ve Onkoloji Bilim Dalı, Istanbul, Türkiye

i. Çağlar 0000-0003-3508-3531 Aydın Kadın Doğum ve Çocuk Hastanesi, Çocuk Enfeksiyon Hastalıkları Bilim Dalı, Aydın, Türkiye

N. Bayram 0000-0003-1802-2518

i. Devrim 0000-0002-6053-8027 Dr. Behçet Uz Çocuk Hastalıkları ve Cerrahisi Eah, Çocuk Enfeksiyon Hastalıkları Bilim Dalı, Izmir, Türkiye
S. Okur Acar 0000-0002-5768-0890 


\section{INTRODUCTION}

Congenital neutropenia (CN) is defined as chronic neutropenia that arises from a constitutional genetic defect. Severe congenital neutropenia (SCN) and cyclic neutropenia (CyN) are two major types of $\mathrm{CN}$ encountered in childhood ${ }^{(1)}$. Because of the rare onset of SCN, its epidemiology, prognosis and clinical manifestations have not yet been fully understood (2). SCN encompasses a group of disorders that are characterized by peripheral neutrophil counts of $<0.5 \times 10^{9} / \mathrm{L}$, early-onset recurrent bacterial infection and bone marrow maturation arrest of myelopoiesis at the promyelocyte/myelocyte stage ${ }^{(2)}$. Different mutations in the neutrophil elastase gene (ELANE) are responsible for the majority of the patients. Other gene mutations associated with $\mathrm{SCN}$ are in the genes of HAX-1, G6PC-3, GFI-1, WAS, JAGN and GATA-2. In addition, the glycogen storage disease type Ib (GSD-Ib) is a metabolic disorder that may cause congenital neutropenia ${ }^{(3)}$.

Infections are an important cause of morbidity and mortality in patients with $\mathrm{CN}$. Before the availability of G-CSF treatment, almost all the patients with severe neutropenia died in the first two years of life due to infectious complications. The management of the disease changed with the administration of broad-spectrum antibiotics and G-CSF treatment. Despite these novel treatment strategies, infections are still a significant problem for this group of patients. Patients have frequently been suffering from severe and recurrent bacterial infections that may affect the skin, lungs and deep tissues ${ }^{(1,3)}$.

In the literature, there are few studies investigating the type and frequency of infections in children with $\mathrm{CN}^{(1,4)}$, which has remained underresearched. In the present study, we report on the incidence, type, localization of documented infections, the clinical features and long-term outcome in patients with $\mathrm{CN}$.

\section{MATERIAL and METHODS}

\section{Collection and Analysis of Clinical Data}

We performed a retrospective chart review of children with neutropenia seen at our hospital from 2000-2018, using patients' files and an electronic data system. The data of 15 patients with congenital neutropenia were included in this study. We collected clinical data, including age, sex, absolute neutrophil count (ANC), genetic mutation analysis, treatments received, infectious complications and outcome.

\section{Definitions}

Neutropenia: Neutropenia is defined as mild if circulating neutrophils are between 1.0 and $1.5 \times 10^{9} / \mathrm{L}$, as moderate if between 0.5 and $1.0 \times 10^{\%} / \mathrm{L}$, and severe if below $0.5 \times 10^{9} / \mathrm{L}$. Neutrophil counts below $0.2 \times 10^{9} / \mathrm{L}$ are defined as very severe congenital neutropenia. SCN is an immunodeficiency diagnosed using modified conventional criteria includes; onset at early ages, primary myelopoiesis failure with an absolute neutrophil count (ANC) $<0.5 \times 10^{9} / L$, severe infections and risk of leukemic transformation ${ }^{(3)}$.

Mutations Analysis: In this study, analysis of genetic mutations causing SCN was performed. DNA was extracted from a 200- $\mu \mathrm{L}$ peripheral blood sample using the QIAamp DNA blood Mini Qlcube Kit with a QIcube instrument (QIAGEN, Hilden, Germany) according to the manufacturer's specifications. Analysis of sequencing data were conducted by using the Integrative Genomics Viewer (Thorvaldsd ottir et al., 2013).

\section{Statistical Methods}

The data were analyzed using SPSS Statistics 17.0 (International Business Machines Corp, Armonk, NY). The Kolmogorov-Smirnov test was used to investigate whether the distribution of continuous variables was approximately normal, and the Levene test was used to investigate whether the assumption of homogeneity of variance was met. Baseline characteristics were given as medians and interquartile ranges (IQRs) for continuous variables, and numbers of cases and percentages were calculated for categorical variables. To conduct this study, ethical approval was obtained from the local ethics committee of Dr. Behcet Uz Children's Hospital. 
Table 2. The Clinical and Laboratory Characteristics of the Patients

\begin{tabular}{|c|c|c|c|c|c|c|c|c|c|c|}
\hline Patient & $\begin{array}{l}\text { Age at diag. } \\
\text { (month)/Sex }\end{array}$ & $\begin{array}{c}\text { ANC at } \\
\text { diag. } \times 10^{9} / \mathrm{L}\end{array}$ & $\begin{array}{l}\text { Genetic } \\
\text { Mutation }\end{array}$ & $\begin{array}{l}\text { Infection Leading } \\
\text { to the Diag. }\end{array}$ & $\begin{array}{c}\text { Follow-up } \\
\text { duration (month) }\end{array}$ & $\begin{array}{l}\text { G-CSF } \\
\text { Treat. }\end{array}$ & $\begin{array}{l}\text { Episode } \\
\text { of hosp. }\end{array}$ & $\begin{array}{c}\text { Type of } \\
\text { Infections }\end{array}$ & $\begin{array}{c}\text { Bacterial culture } \\
\text { growth }\end{array}$ & $\begin{array}{l}\text { Episode of hosp. } \\
\text { Per month }\end{array}$ \\
\hline P1 & $90 / F$ & 0.20 & - & URTI & 122 & - & 1 & Pneumonia & ND & 0.008 \\
\hline P2 & $11 / \mathrm{M}$ & 0.30 & $\begin{array}{c}\text { HAX-1 } \\
\text { c.130-131insA } \\
\text { (homozygous) }\end{array}$ & $\begin{array}{l}\text { HLH secondary to } \\
\text { CMV infection }\end{array}$ & 108 & Continue & 5 & $\begin{array}{c}\text { Hlh } \\
\text { Pneumonia } \\
\text { Anal abscess } \\
\text { Stomatitis }\end{array}$ & ND & 0.04 \\
\hline P3 & $76 / \mathrm{M}$ & 0.15 & $\begin{array}{c}\text { HAX-1 } \\
\text { c.130-131insA } \\
\text { (homozygous) }\end{array}$ & Pneumonia & 141 & Continue & 8 & $\begin{array}{l}\text { Pneumonia } \\
\text { Fever } \\
\text { Cellulitis } \\
\text { Tonsillitis }\end{array}$ & $\begin{array}{c}\text { HC (-) } \\
\text { UC (-) } \\
\text { Wound } \\
\text { culture: Staph } \\
\text { aureus }\end{array}$ & 0.05 \\
\hline P4 & $84 / \mathrm{M}$ & 0.20 & $\begin{array}{c}\text { HAX-1 } \\
\text { c.130-131insA } \\
\text { (homozygous) }\end{array}$ & $\begin{array}{l}\text { HLH secondary to } \\
\text { EBV infection }\end{array}$ & 141 & Continue & 10 & $\begin{array}{c}\text { Fever } \\
\text { Stomatitis } \\
\text { Viral infection } \\
\text { Pneumonia } \\
\text { EBV-HLH }\end{array}$ & $\begin{array}{l}\mathrm{HC}(-) \\
\mathrm{UC}(-)\end{array}$ & 0.07 \\
\hline P5 & $33 / \mathrm{M}$ & 0.38 & - & AGE & 42 & Continue & 3 & $\begin{array}{l}\text { Pneumonia } \\
\text { Fever }\end{array}$ & $\begin{array}{l}\mathrm{HC}(-) \\
\mathrm{UC}(-)\end{array}$ & 0.07 \\
\hline P6 & $34 / F$ & 0.20 & - & Stomatitis & 38 & - & 3 & $\begin{array}{l}\text { Fever } \\
\text { URTI }\end{array}$ & $\begin{array}{l}\mathrm{HC}(-) \\
\mathrm{UC}(-)\end{array}$ & 0.07 \\
\hline P7 & $11 / F$ & 0.30 & $\begin{array}{c}\text { HAX-1 } \\
\text { c.130-131insA } \\
\text { (homozygous) }\end{array}$ & Pneumonia & 48 & - & 6 & $\begin{array}{l}\text { Pneumonia } \\
\text { Stomatitis }\end{array}$ & ND & 0.12 \\
\hline P8 & $75 / F$ & 0.47 & $\begin{array}{c}\text { HAX-1 } \\
\text { c.130-131insA } \\
\text { (homozygous }\end{array}$ & Pneumonia & 19 & - & 4 & $\begin{array}{l}\text { Pneumonia } \\
\text { Abscess }\end{array}$ & $\begin{array}{c}\text { UC (-) } \\
\text { Wound culture: } \\
\text { Staf aureus }\end{array}$ & 0.21 \\
\hline P9 & $77 / F$ & 0.50 & $\begin{array}{c}\text { HAX-1 } \\
\text { c.130-131insA } \\
\text { (homozygous) }\end{array}$ & Stomatitis & 43 & - & None & - & ND & 0 \\
\hline P10 & $150 / F$ & 0.20 & $\begin{array}{c}\text { HAX-1 } \\
\text { c.130-131insA } \\
\text { (homozygous) }\end{array}$ & $\begin{array}{l}\text { Cutaneous } \\
\text { Abscess }\end{array}$ & 28 & Continue & 14 & $\begin{array}{l}\text { Pneumonia } \\
\text { Inguinal abscess }\end{array}$ & $\mathrm{HC}(-)$ & 0.5 \\
\hline P11 & $11 / \mathrm{M}$ & 0.20 & $\begin{array}{l}\text { ELANE } \\
19 p 13.3\end{array}$ & Preseptal selulitis & 16 & Continue & 9 & $\begin{array}{c}\text { Fever } \\
\text { Cellulitis } \\
\text { Stomatitis } \\
\text { Abscess } \\
\text { Otitis } \\
\text { Pneumonia } \\
\text { URTI }\end{array}$ & $\begin{array}{c}\mathrm{HC}(-) \\
\text { Wound } \\
\text { culture: Staf } \\
\text { aureus }\end{array}$ & 0.56 \\
\hline P12 & $8 / \mathrm{F}$ & 0.48 & $\begin{array}{c}\text { ELANE } \\
\text { c. } 254 \mathrm{G} \mathrm{A} \\
\text { (heterozygous) }\end{array}$ & $\begin{array}{l}\text { Cutaneous } \\
\text { Abscess }\end{array}$ & 14 & - & 1 & Anal abscess & $\mathrm{HC}(-)$ & 0.07 \\
\hline P13 & $5 / M$ & 0.07 & $\begin{array}{c}\text { SLC37A4 } \\
\text { Glycogen } \\
\text { Storage Type } 1\end{array}$ & Pneumonia & 137 & Continue & 7 & $\begin{array}{c}\text { Fever } \\
\text { Pneumonia }\end{array}$ & ND & 0.05 \\
\hline P14 & $4 / F$ & 0.20 & $\begin{array}{c}\text { G6PC3 } \\
\text { IVS3-1 GC } \\
\text { (g.4234G C) } \\
\text { (homozygous) }\end{array}$ & Pneumonia & 179 & Continue & 13 & $\begin{array}{c}\text { Fever } \\
\text { Acute } \\
\text { Gastroenteritis } \\
\text { Pneumonia }\end{array}$ & $\begin{array}{l}\mathrm{HC}(-) \\
\mathrm{UC}(-)\end{array}$ & 0.07 \\
\hline P15 & $51 / F$ & 0.15 & - & Stomatitis & 91 & Continue & 3 & $\begin{array}{c}\text { Stomatitis } \\
\text { Fever }\end{array}$ & $\begin{array}{l}\text { HC (-) } \\
\text { UC (-) }\end{array}$ & 0.03 \\
\hline
\end{tabular}

CN; congenital neutropenia, ANC; absolute neutrophil count, G-CSF; granulocyte colony-stimulating factor, MDS; myelodysplastic syndrome, AML; acute myeloid leukemia, URTI; upper respiratory tract infection, HLH; hemophagocytic lymphohistiocytosis, CMV; cytomegalovirus, EBV; Epstein-Barr virus, AGE; acute gastroenteritis, HC; hemoculture, UC; urine culture, (-); negative, (+); positive, ND; not done. 


\section{RESULTS}

Fifteen patients (six boys, nine girls) with $\mathrm{CN}$ were analyzed retrospectively in this study. The median age at diagnosis was 34 months (range, four months150 months), and the median follow-up time was 48 months (range, 13-179 months). Nine of the 15 patients were from the consanguineous marriage. Skeleton dysplasia was not observed in any of them. The detected mutations were HAX-1 in seven (46\%) patients, ELANE in two patients (13\%), G6PC3 in one patient (6\%) and SLC37A4 in one patient (6\%). None of the mutations related to the SCN was detected in four patients (26\%). The median ANC at diagnosis was $0.29 \times 10^{9} / \mathrm{L}\left(0.07-0.43 \times 10^{9} / \mathrm{L}\right)$. The main causes of hospital admission before the establishment of the diagnosis were upper respiratory tract infection (URTI) in six patients, pneumonia in four patients, gingival stomatitis in three patients and soft tissue infection in two patients. The number of patients were diagnosed while being treated for other diseases was as follows: Five patients during pneumonia treatment, three patients during stomatitis treatment, two patients during skin abscess treatment, one patient during acute gastroenteritis treatment and one patient during URTI treatment. The congenital neutropenia (CN) was diagnosed in two patients when they presented with the clinical manifestation of hemophagocytic lymphohistiocytosis (HLH), which was secondary to viral infection (CMV and EBV). The clinical and laboratory characteristics of the patients are presented in Table 1 in summary.

Fourteen (93\%) of the patients were hospitalized with infection at least once in a lifetime. No hospitalization was required for one patient (P9) during the follow-up. However, this patient had to use oral antibiotics due to chronic gingivitis, otitis, and recurrent stomatitis attacks. The mutation analysis and neutrophil count of her confirmed the diagnosis of $\mathrm{CN}$. The total hospitalization period of patients contained 662 days and 87 infection episodes. We obtained 74 hospitalization episodes. We were able to access information on seventy-four hospitalization episodes, which were due to infections. The most common reasons were pneumonia (35\%), fever (21\%), stomatitis (16\%), cutaneous and deep soft tissue infections (12\%). These episodes accounted for $84 \%$ of the total. Blood culture samples were taken from nine patients during their hospitalization periods, and no bacterial growth was detected in any of them (Table 1). Due to early-onset recurrent lung infections before the diagnosis, bronchiectasis developed in one patient (P10) who suffered from severe pneumonia frequently. On the other hand, with the initiation of G-CSF treatment, pneumonia attacks of her were relatively diminished. Sixty percent of all patients (9/15) were treated using G-CSF. An initial dose of G-CSF was $3 \mathrm{mcg} / \mathrm{kg} / \mathrm{day}$, and the dose was subsequently modified according to the patient's response. Target ANC level was $1-5 \times 10^{9} / \mathrm{L}$. The mean dose of G-CSF was $3.5 \pm 0.69$ (max: 10 ) $\mathrm{mcg} / \mathrm{kg} / \mathrm{day}$; the mean administration duration was $49.8 \pm 18.8$ (max: 139) months. Despite the administration of high-dose G-CSF treatment (10 mcg/kg/day), P11 did not respond and achieved ANC $>0.5 \times 10^{9} / \mathrm{L}$. He continued to suffer from severe infections. Therefore, hematopoietic stem cell transplantation (HSCT) from a sibling donor was performed. He was alive after ten months of the HSCT. Yearly bone marrow surveillance was performed for each patient under G-CSF treatment. Morphological evaluation and genetic analysis, including trisomy $8,5 p$ deletion, 20q deletion, $7 q$ deletion, were taken to determine myelodysplastic syndrome/acute myeloid leukemia (MDS/AML). None of the patients developed MDS/ AML during follow-up. No death due to infections or any other cause was encountered in any of the patients during their follow-up.

\section{DISCUSSION}

Infections are the major and life-threatening complications of patients with CN. Currently, with the new treatment strategies, the quality and duration of life have improved ${ }^{(3)}$. Although G-CSF administration is associated with decreased frequency and severity of infections, there are few studies documenting the clinical characteristics of 
infections ${ }^{(1,4)}$. In our study, the median age at diagnosis was 34 months (range, four months- 150 months), and it was older compared with the other studies ${ }^{(1,5-7)}$. In the literature, most of the patients were diagnosed at an early age because of the encountered infections at unexpected sites $(1,4)$. According to Fioredda et al. ${ }^{(5)}$, the median age at diagnosis was eight months. On the other hand, the average age at diagnosis was determined as $\mathbf{1 6 . 5}$ months and 25.8 months in studies conducted in our country ${ }^{(8,9)}$. Given the studies conducted in Turkey, it is seen that the average age at diagnosis is relatively high. Possible underlying reasons for this delay can be explained as follows: Complete blood count (CBC) may not require due to mild symptoms at the patient's admission or the Absolute Neutrophil Count (ANC) in the complete blood count may be high due to the patient's ongoing infection, and the diagnosis may therefore have been overlooked or although the ANC value of the patient is low, this situation may be linked with neutropenia related to infection. Thus, $\mathrm{CN}$ has not been considered in the differential diagnosis. Lastly, the diagnosis of $\mathrm{CN}$ may be considered and the parents may have been informed accordingly. However, despite this, they might not have been applied to the hematology clinic. We investigated the clinical features of the patients with $\mathrm{CN}$ who were followed up in our clinic. The main cause of hospital admission before establishing the diagnosis was URTI, which was consistent with a previous report that described all seven patients who suffered from recurrent URTI during the first six months ${ }^{(1)}$. In a study in which chronic severe neutropenia cases were examined, URTIs were the most common cause of complaints ${ }^{(2)}$.

Seventy-four hospitalization episodes were observed, and the most common causes of hospitalizations were pneumonia, fever and stomatitis, respectively. In other studies, cutaneous and soft tissue infections, pneumonia and fever were reported as the most common causes $(1,4)$. However, a small part of our patients (12\%) had cutaneous and soft tissue infections. The most common pathogens causing infections in neutropenic patients are S. au-reus and gram-negative bacteria
(10). No bacterial growth was detected in the blood culture sampling results of any patient during the follow-up. However, S.aureus was isolated from wound culture samples taken from three patients with a diagnosis of soft tissue infection. In a previous study, gram-negative rods were the most common source of infection in patients diagnosed with $\mathrm{CN}^{(10)}$. Interestingly, there is only one case series, which includes our two patients with $\mathrm{CN}$ that arise from HAX1 mutation who have presented with $\mathrm{HLH}^{(11)}$. Authors explained this by mutations in the HAX1 gene severely diminish the function of HCLS1, which plays an essential role in G-CSF-mediated granulopoiesis.

$\mathrm{CN}$ is a genetically heterogeneous disorder. More than 20 gene mutations, including HAX, ELANE and G6PC3, have been demonstrated. However, $25 \%$ of the $\mathrm{CN}$ patients' genetic basis remains unknown (12-15). Similarly, 26\% (4/15) of our patients' mutation was not able to be determined. ELANE mutation, an inherited autosomal dominant condition, is responsible for $50-60 \%$ of patients ${ }^{(16-20)}$. However, approximately $50 \%$ of our patients had HAX -1 mutation, as compatible with the national data of our country ${ }^{(9)}$. This finding can be explained by the consanguinity between our patients' parents. Three of seven patients (P7, P8 and P9) with HAX-1 mutation were the same family members. Despite having the same HAX-1 mutation, these three patients had different clinical features concerning infection frequency. This finding suggests that besides mutations, environmental and epigenetic factors may also play a role in clinical features ${ }^{(10)}$. Patients progressing with varying clinical courses despite carrying the same mutation have also been reported in the literature ${ }^{(8)}$. Glycogen storage disease type $\mathrm{Ib}$ (GSD-Ib) is a metabolic disorder that may cause severe congenital neutropenia. It is characterized by neutropenia and myeloid dysfunctions. Despite the large knowledge about the metabolic component of the disease, the pathophysiology of neutropenia has been unclear. Patients can be treated with G-CSF to prevent severe infections. In the literature, patients with GSD-1b have been reported to develop AML ${ }^{(21)}$. We have one GSD-1b patient (P13), and he has been 
under treatment of G-CSF. With the regular bone marrow examinations, AML/MDS has been excluded.

It was proven that in the management of $\mathrm{CN}$, G-CSF is an effective first-line treatment for preventing life-threatening infection complications at the dose of 3-10 mcg/kg/day. The Severe Chronic Neutropenia International Registry (SCNIR) reported that $95 \%$ of the patients with SCN responded to G-CSF treatment (10). Sixty percent of our patients were under treatment of G-CSF, and most of them (except two patients) responded as clinical and laboratory to the treatment in our study. Despite being under the treatment of G- CSF, one patient (P14) had several episodes of infections. This can be explained by that neutrophil functions are not completely normal despite the increase in neutrophil counts with G-CSF ${ }^{(22,23)}$. On the other hand, permanent organ damage, such as chronic inflammatory bowel disease, may lead to additional co-morbidities to increase the amount of recurrent infections and hospitalizations. HSCT was not considered in this patient. Because although he had been continued to suffer from infection attacks, none of them was severe and his clinical course was milder. Despite the administration of G-CSF at 10 $\mathrm{mcg} / \mathrm{kg} /$ day, one patient (P11) continued to have severe infections, and during follow-up, his ANC level was below $0.5 \times 10^{9} / \mathrm{L}$. Therefore, HSCT was performed.

Although the average survival in these patients has reached $80 \%$ with the new developments, approximately $10 \%$ of them are still dying due to sepsis. During our study, we did not encounter any sepsis-related deaths. In a study, it was reported that six of 101 patients died because of sepsis and severe infections, while in this case series, no patient was treated using G-CSF ${ }^{(6)}$.

$\mathrm{SCN}$ is a premalignant disease, and that this risk is increased by G-CSF administration. Leukemic progression in SCN is strongly associated with acquired somatic mutations in the CSF3R (Colony Stimulating Factor 3 Receptor) gene, which encodes the G-CSF receptor ${ }^{(20)}$. In our study, the mean G-CSF dosage was $3.5 \pm 0.69 \mathrm{mcg} / \mathrm{kg} /$ day (max: $10 \mathrm{mcg} / \mathrm{kg} /$ day); the mean administration duration was
49.8 \pm 18.8 months (max: 139 months). None of our patients developed MDS/AML, while we could give 10-year survival rates in the future. SCNIR data demonstrated that the cumulative incidence of MDS/ AML in the 15 -year follow-up was $22 \%{ }^{(24,25)}$. This rate was reported at $11 \%$ and $31 \%$ in the French Severe Chronic Neutropenia Registry (SCNFR) and the Swedish Registry, respectively. However, the effects of duration and dose on this development are not clear. In recent studies, patients requiring greater than $8 \mu \mathrm{g} / \mathrm{kg} /$ day of G-CSF had a cumulative incidence of MDS/AML of $40 \%$ after 10 years ${ }^{(10)}$.

In conclusion, $\mathrm{CN}$ is a rarely encountered clinical picture. The management of infectious complications in $\mathrm{CN}$ is vital. Early diagnosis is crucial to preventing infections and permanent organ damage. The history of having frequent URTIs may be the first clue to consider the diagnosis of $\mathrm{CN}$ in these patients. However, it should be kept in mind that the clinical findings of the patients may vary despite having the same mutation.

This study has some limitations due to its retrospective design. First of all, cases with $\mathrm{CN}$ were reviewed from the medical files and electronic data of the patients. However, we confirmed the infections from the microbiology laboratories, especially for bloodstream infections and the radiology department for pneumonia.

Ethics Committee Approval: S.B.Ü. Izmir Dr. Behçet Uz Pediatric Diseases and Surgery Training and Research Hospital Ethics Committee approval was obtained (2021/477).

Conflict of Interest: The authors declare that there is no conflict of interest in this paper.

Funding: There is no financial support for this article. Informed Consent: Since our study was retrospective, consent was not obtained from the patients.

\section{REFERENCES}

1. Shu Z, Li XH, Bai XM, Zhang ZY, Jiang LP, Tang XM, et al. Clinical characteristics of severe congenital neutropenia caused by novel ELANE gene mutations. Pediatr Infect Dis J. 2015;34(2):203-7.

https://doi.org/10.1097/INF.0000000000000522

2. Lee N, Lee BC. Incidence of severe chronic neutropenia in 
South Korea and related clinical manifestations: A National Health Insurance Database Study. Medicina (Kaunas). 2020;56(6):262.

https://doi.org/10.3390/medicina56060262

3. Donadieu J, Beaupain B, Mahlaoui N, Bellanné-Chantelot C. Epidemiology of Congenital Neutropenia. Hematol Oncol Clin N Am 2013;27:1-17.

https://doi.org/10.1016/j.hoc.2012.11.003

4. Fioredda F, Calvillo M, Burlando O, Riccardi F, Caviglia I, Tucci $F$, et al. Infectious complications in children with severe congenital, autoimmune or idiopathic neutropenia: a retrospective study from the Italian Neutropenia Registry. Pediatr Infect Dis J. 2013;32(4):410-2. https://doi.org/10.1097/INF.0b013e3182814b5a

5. Fioredda F, Calvillo M, Lanciotti M, Cefalo MG, Tucci F, Farruggia $\mathrm{P}$,et al. Lethal sepsis and malignant transformation in severe congenital neutropenia: report from the Italian Neutropenia Registry. Pediatr Blood Cancer. 2015;62(6):1110-2. https://doi.org/10.1002/pbc.25401

6. Donadieu J, Leblanc T, Bader Meunier B, Barkaoui M, Fenneteau O, Bertrand $Y$, et al. Analysis of risk factors for myelodysplasias, leukemias and death from infection among patients with congenital neutropenia. Experience of the French Severe Chronic Neutropenia Study Group. Haematologica. 2005;90(1):45-53.

7. Saettini F, Mantovani P, De Lorenzo P, Biondi A, Bonanomi S. Severe and recurrent infections identify severe congenital neutropenia and primary immunodeficiencies in pediatric isolated neutropenia. Clin Immunol. 2021;223:108643. https://doi.org/10.1016/j.clim.2020.108643

8. Aydogmus C, Cipe F, Tas M, Akinel A, Öner Ö, Keskindemirci $G$, et al. HAX-1 deficiency: Characteristics of five cases including an asymptomatic patient. Asian Pac J Allergy Immunol. 2016;34(1):73-6.

https://doi.org/10.12932/AP0618.34.1.2016

9. Yılmaz Karapınar D, Patıroğlu T, Metin A, Çalışkan Ü, Celkan T, Yılmaz B, et al. Homozygous c.130-131 ins A (pW44X) mutation in the HAX1 gene as the most common cause of congenital neutropenia in Turkey: Report from the Turkish Severe Congenital Neutropenia Registry. Pediatr Blood Cancer. 2019;66(10):e27923.

https://doi.org/10.1002/pbc.27923

10. Cho HK, Jeon IS. Different clinical phenotypes in familial severe congenital neutropenia cases with same mutation of the ELANE gene. J Korean Med Sci. 2014;29(3):452-5. https://doi.org/10.3346/jkms.2014.29.3.452

11. Karapınar TH, Yılmaz Karapinar D, Oymak Y, Ay Y, Demirağ B, Aykut $A$, et al. HAX1 mutation positive children presenting with haemophagocytic lymphohistiocytosis. $\mathrm{Br} J$ Haematol. 2017;177(4):597-600. https://doi.org/10.1111/bjh.14574

12. Xia J, Bolyard AA, Rodger E, Stein S, Aprikyan AA, Dale DC, et al. Prevalence of mutations in ELANE, GFI1, HAX1, SBDS, WAS and G6PC3 in patients with severe congenital neutropenia. Br J Haematol. 2009;147(4):535-42. https://doi.org/10.1111/j.1365-2141.2009.07888.x

13. Dhanraj S, Matveev A, Li H, Lauhasurayotin S, Jardine L, Cada $M$, et al. Biallelic mutations in DNAJC21 cause ShwachmanDiamond syndrome. Blood. 2017;16;129(11):1557-62. https://doi.org/10.1182/blood-2016-08-735431

14. Donadieu J, Beaupain B, Fenneteau O, Bellanné-Chantelot C. Congenital neutropenia in the era of genomics: classification, diagnosis, and natural history. Br J Haematol. 2017;179(4): 557-74. https://doi.org/10.1111/bjh.14887

15. Bellanné-Chantelot C, Schmaltz-Panneau B, Marty C, Fenneteau O, Callebaut I, Clauin S, et al. Mutations in the SRP54 gene cause severe congenital neutropenia as well as Shwachman-Diamond-like syndrome. Blood. 2018;132(12): 1318-31. https://doi.org/10.1182/blood-2017-12-820308

16. Boxer LA, Newburger PE. A molecular classification of congenital neutropenia syndromes. Pediatr Blood Cancer. 2007;49(5):609-14.

https://doi.org/10.1002/pbc.21282

17. Zeidler C, Germeshausen M, Klein C, Welte K. Clinical implications of ELA2-, HAX1-, and G-CSF-receptor (CSF3R) mutations in severe congenital neutropenia. $\mathrm{Br} J$ Haematol. 2009;144(4):459-67. https://doi.org/10.1111/j.1365-2141.2008.07425.x

18. Boztug K, Appaswamy G, Ashikov A, Schäffer AA, Salzer U, Diestelhorst J, et al. A syndrome with congenital neutropenia and mutations in G6PC3. N Engl J Med. 2009;360(1):32-43. https://doi.org/10.1056/NEJMoa0805051

19. Boztug K, Klein C. Genetic etiologies of severe congenital neutropenia. Curr Opin Pediatr. 2011;23(1):21-26. https://doi.org/10.1097/MOP.0b013e32834262f8

20. Link DC. Mechanisms of leukemic transformation in congenital neutropenia. Curr Opin Hematol. 2019;26(1):3440. https://doi.org/10.1097/MOH.0000000000000479

21. Chou JY, Jun HS, Mansfield BC. Neutropenia in type Ib glycogen storage disease. Curr Opin Hematol. 2010 Jan;17(1):36-42.

https://doi.org/10.1097/MOH.0b013e328331df85

22. Donini M, Fontana S, Savoldi G, Vermi W, Tassone L, Gentili F, et al. G-CSF treatment of severe congenital neutropenia reverses neutropenia but does not correct the underlying functional deficiency of the neutrophil in defending against microorganisms. Blood. 2007;109(11):4716-23. https://doi.org/10.1182/blood-2006-09-045427

23. Goenka A, Doherty JA, Al-Farsi T, Jagger C, Banka S, Cheesman E, Fagbemi A, Hughes SM, Wynn RF, Hussell T, Arkwright PD. Neutrophil dysfunction triggers inflammatory bowel disease in G6PC3 deficiency. J Leukoc Biol. 2020 Sep 15. Epub ahead of print. PMID: 32930428. https://doi.org/10.1002/JLB.5AB1219-699RR

24. Rosenberg PS, Alter BP, Bolyard AA, Bonilla MA, Boxer LA, Cham B, et al. Severe Chronic Neutropenia International Registry. The incidence of leukemia and mortality from sepsis in patients with severe congenital neutropenia receiving long-term G-CSF therapy. Blood. 2006;107(12): 4628-35.

https://doi.org/10.1182/blood-2005-11-4370

25. Skokowa J, Dale DC, Touw IP, Zeidler C, Welte K. Severe congenital neutropenias. Nat Rev Dis Primers. 2017;3:17032.

https://doi.org/10.1038/nrdp.2017.32 